\title{
Farmed salmonids drive the abundance, ecology and evolution of parasitic salmon lice in Norway
}

\author{
T. Dempster ${ }^{1, *}$, K. Overton ${ }^{1}$, S. Bui ${ }^{2}$, L. H. Stien ${ }^{2}$, F. Oppedal ${ }^{2}$, Ø. Karlsen ${ }^{3}$, \\ A. Coates ${ }^{1,4}$, B. L. Phillips ${ }^{4}$, L. T. Barrett ${ }^{1}$ \\ ${ }^{1}$ Sustainable Aquaculture Laboratory - Temperate and Tropical (SALTT), School of BioSciences, University of Melbourne, \\ Victoria 3010, Australia \\ ${ }^{2}$ Institute of Marine Research, Matre Research Station, 5984 Matredal, Norway \\ ${ }^{3}$ Institute of Marine Research, Nordnesgaten 50, 5005 Bergen, Norway \\ ${ }^{4}$ Spatial Ecology and Evolution Lab (SPEEL), School of BioSciences, University of Melbourne, Victoria 3010, Australia
}

\begin{abstract}
Sea cage fish farming is typically open to the environment, with disease transmission possible between farmed and wild hosts. In salmonid aquaculture, salmon louse Lepeophtheirus salmonis infestations cause production losses, reduce welfare for farmed fish and increase infestation rates for wild fish populations. The high density of hosts in farms likely also shifts the coevolutionary arms race between host and parasite, with ecological and evolutionary consequences for the salmon louse. Using farm-reported salmon and louse abundances and publicly reported estimates of wild salmonid host abundances and the salmon lice they carry, we estimated (1) the relative abundance of farmed and wild salmonid hosts and (2) the relative importance of each for the abundance of salmon lice for the coastal zone of Norway from 1998 to 2017. Farmed hosts increased in importance over time with the expansion of the industry. From 2013 to 2017, farmed salmonids outnumbered wild salmonids by $267-281: 1$. By 2017 , farmed salmonids accounted for $99.6 \%$ of available hosts and produced $99.1 \%$ of adult female salmon lice and $97.6 \%$ of mated (ovigerous) adult female salmon lice in Norwegian coastal waters. The persistent dominance of farmed hosts has clear implications: (1) management decisions that aim to limit lice abundance can be guided by lice data from farms alone, as lice on wild salmonids make a trivial contribution to the national lice population; and (2) strategies to prevent or treat lice infestations are vulnerable to the evolution of resistance, as the pool of wild hosts is inconsequential and will not act as a refuge large enough to stem the evolution of resistance. As the Norwegian salmon industry expands and salmon lice infestations continue, farmed salmon will drive the ecology and evolution of salmon lice.
\end{abstract}

KEY WORDS: Aquaculture $\cdot$ Host-parasite coevolution $\cdot$ Host availability $\cdot$ Lepeophtheirus salmonis $\cdot$ Resistance $\cdot$ Salmo salar $\cdot$ Sea lice

\section{INTRODUCTION}

Industrial aquaculture is a relatively modern phenomenon (Duarte et al. 2007), with most farmed species still at the lowest level of domestication (Teletchea \& Fontaine 2014) and held in systems that are open to the environment, leaving stock vulnera-

${ }^{*}$ Corresponding author: dempster@unimelb.edu.au ble to pathogens. Once present, the high density of hosts within farms facilitates rapid pathogen propagation, and as a result, severe outbreaks have occurred for almost all fish species cultured in open systems (Kent 2000, Bondad-Reantaso et al. 2005).

Parasites are a key concern for fish farming, leading to production losses and poor welfare for billions 
of animals either directly (Barber 2007) or indirectly via the side effects of control measures (Overton et al. 2019). Moreover, because industrial farming increases the abundance of farmed hosts, infestations on farmed fish can have serious consequences for wild fish populations; the large number of hosts within farms typically amplifies the number of infective stage parasites that flow to the wider environment, spilling over to increase infestation in wild fishes (Krkošek et al. 2013, Serra-Llinares et al. 2016, Bouwmeester et al. 2021). Artificial conditions within farms also establish new settings for the coevolutionary arms race between host and parasite, with ecological and evolutionary consequences for parasites as they adapt to farmed fish and farming practices (Mennerat et al. 2010, Kennedy et al. 2016, Nowak 2007, Coates et al. 2021).

Salmonids (principally Atlantic salmon Salmo salar but also rainbow trout Oncorhynchus mykiss) are the most produced fish in the marine environment, with a global production of $\sim 3$ million $\mathrm{t} \mathrm{yr}^{-1}$ (FAO 2020). The largest producer is Norway, where nearly 700 farming locations in coastal waters hold $>400$ million Atlantic salmon and rainbow trout in open sea cages (Norwegian Directorate of Fisheries 2020a). Rapid expansion since the birth of the industry in the 1960s has fundamentally shifted the transmission dynamics for ectoparasitic salmon lice Lepeophtheirus salmonis (Caligidae) in the Norwegian coastal zone, with important implications for the ecology and evolution of wild salmonids as well as salmon lice (Torrissen et al. 2013). Rapid evolution of louse life history traits has already occurred in Norway (Mennerat et al. 2017), along with resistance to multiple common delousing chemicals (Besnier et al. 2014, Aaen et al. 2015). Strategies that seek to prevent infestations from occurring may also be vulnerable to the evolution of resistance if farmed salmon make up a sufficient proportion of available hosts for salmon lice (Barrett et al. 2020, Coates et al. 2021).

High lice loads on wild salmonids during the 1990s in Norway were partly attributed to salmonid farming and prompted the introduction of maximum lice thresholds in farms (updated legislation: Norwegian Ministry of Trade and Fisheries 2012), together with annual monitoring programs designed to track lice loads on wild Atlantic salmon, Arctic charr Salvelinus alpinus and wild brown sea trout Salmo trutta (Bjørn et al. 2001, 2002, 2003, 2005, 2007, 2008, 2009, 2010). Simultaneously, a Norwegian salmon lice dispersal model was developed to complement these efforts by predicting infestation pressure based on lice abundance in farms and environmental parameters that influence the dispersal of lice larvae (Asplin et al. 2004, 2014, Johnsen et al. 2014, Sandvik et al. 2016). Predictions from the lice dispersal model are used to calculate likely infestation pressures on outmigrating salmon in spring, and this contributes to the evidence an expert panel uses to set limits on farmed biomass for each farming region (the 'traffic light' system) with the goal of minimising infestation pressure on wild salmonids (Norwegian Ministry of Trade and Fisheries 2017, Myksvoll et al. 2018, Johnsen et al. 2021). Lice dispersal model predictions have generally mapped closely to observed infestation pressure in sentinel cages (Sandvik et al. 2016, 2020) and on wild salmon (Myksvoll et al. 2018), and they do this without accounting for lice larvae that arise from wild hosts (e.g. Johnsen et al. 2014, Skarðhamar et al. 2018). Soon after the legislation was passed to first set lice limits on farms, Heuch \& Mo (2001) modelled salmon lice egg production under past and future scenarios and suggested that as early as 2001, farms were responsible for most louse eggs produced.

Since Heuch \& Mo's (2001) initial salmon lice production estimate, farmed salmonid numbers have increased 2.4 times in Norwegian coastal waters, and $\sim 20 \mathrm{yr}$ of lice density data have been collected from farmed and wild salmonids. Here, we use publicly available data on wild and farmed host numbers and reported lice abundances on farmed and wild hosts to estimate the relative importance of farmed and wild hosts as reservoirs for salmon lice over the last 2 decades.

\section{METHODS}

For each year from 1998 to 2017, we estimated the proportion of total host and louse populations contributed by hosts and lice within farms $\left(P_{H}\right.$ and $P_{L^{\prime}}$ respectively). These metrics for the relative importance of farmed salmon hosts account for the seasonal dynamics of fish movement by only counting fish (and lice) that are in the coastal waters during the given year. Lice transmission is considered negligible in offshore locations, and lice cannot survive in freshwater rivers. To make these estimates, we obtained data allowing us to calculate 13 variables describing the mean abundance per fish for farmed and wild salmonids, as well as their seasonal usage of coastal waters. $H$ denotes host numbers (Atlantic salmon Salmo salar and rainbow trout Oncorhynchus mykiss), $L$ denotes mean number of adult female lice per host, and $T$ denotes the proportion of time each host spends in coastal waters. Arctic charr Salvelinus 
alpinus were considered of negligible importance following Heuch \& Mo (2001), as while they are vulnerable to salmon lice infestation, seagoing individuals are rare in all but the northernmost part of the study area. In addition, they stay in the sea at low temperatures and for short durations, $(<6 \mathrm{wk})$ so that any lice they catch seldom develop into adult females (Klemetsen et al. 2003).

The 13 variables we used were as follows:

(1) $H_{F}$ : Average number of farmed salmon and rainbow trout hosts in the sea throughout each year. Monthly number of fish data for 2005 to 2017 were available from the Norwegian Directorate of Fisheries, but monthly data prior to 2005 were not. Therefore, we used the number of farmed salmon and rainbow trout sold as a proxy for the number farmed each year prior to 2015 (Norwegian Directorate of Fisheries 2020a). However, not all fish that are farmed are sold, so a correction factor was necessary. We estimated the correction factor by dividing the number of salmon or trout farmed by the number sold, for each year in 2005 to 2017 (a period for which both data sources were available). On average, there were 1.22 fish farmed for every fish sold, so the annual estimates for 1998 to 2004 were multiplied by 1.22 .

(2) $H_{E S}$ : Number of salmon that escaped from farms, based on data from the Norwegian Directorate of Fisheries (2020b). Research indicates that the total number of farmed salmon escapees is between 2 and 4 times higher than the numbers reported to authorities (Skilbrei et al. 2015). Therefore, we multiplied the reported number of escapees by a factor of 3 .

(3) $H_{E T}$ : Number of rainbow trout that escaped from farms, based on data from the Norwegian Directorate of Fisheries (2020b). To adjust for the underreporting of the number of farmed trout escapees (as above), we also multiplied the reported number of escapees by a factor of 3 .

(4) $H_{W S}$ : Number of wild salmon returns in a given year. Data were sourced from Thorstad \& Forseth (2017). It is assumed that non-returning salmon are offshore of the coastal zone and not important for lice abundance.

(5) $H_{W T}$ : Number of wild brown sea trout in Norway. No comprehensive assessment of wild brown sea trout abundance exists for Norway. In their earlier model, Heuch \& Mo (2001) used an estimate of 1 million, which we have implemented as a constant across years.

(6) $L_{F}$ : Mean adult female lice per farmed salmon and trout. Data for 2005 to 2017 are sourced from legislated reporting from the Norwegian Food Safety Authority. Data from earlier years are sourced from a publicly available database at Lusedata (http://lusedata.no/statistikk/excel). Data were not available for 2000 to 2001, so these years were interpolated by taking the mean of 1999 and 2002.

(7) $L_{E}$ : Adult female lice per fish on escaped salmon and trout. As no data are routinely collected for this in Norway, we used the same values as for $L_{W T}$.

(8) $L_{W S}$ : Mean adult female lice per wild salmon. As no data were routinely collected for this in Norway from 2000 onwards, we used the same values as for $L_{W T}$. For 1998 to 1999, we estimated densities of ovigerous adult female lice per fish according to Norwegian Institute for Nature Research (NINA) reports by Grimnes et al. (1999, 2000). These values were also used to estimate the total number of adult female lice per fish by assuming that ovigerous female lice represented $95 \%$ of all adult female lice (Murray 2002).

(9) $L_{W T}$ : Mean adult female lice per wild sea trout. Data for 2010 to 2017 were sourced from the National Aquaculture Legislation Overview (national monitoring program for salmon lice). Estimates for 2000 to 2004 and 2006 to 2009 were obtained from annual NINA reports (Bjørn et al. 2001, 2002，2003，2004, 2005, 2007, 2008, 2009, 2010). For each year, the number of adult female lice per fish and, if specified, the number of adult female lice with eggstrings per fish were extracted from these reports. Where female and male adult lice were not reported separately, we divided values by 2 to give an estimated mean number of adult female lice per fish. Where there were multiple samples from a site, we took the weighted mean. Due to a shift in funding from the Norwegian Directorate for Nature Management (now Norwegian Environment Agency) to the Norwegian Food Safety Authority, no monitoring data were available from 2005. Therefore, we used the mean of 2004 and 2006 for 2005. For 1998 to 1999, lice data for wild salmon were used (see $L_{W S}$ ).

(10) $T_{F}$ : Proportion of the year that farmed salmon and trout spend in coastal waters. As fish are held in the ocean for the full grow-out period following smoltification, they spend all 12 mo of the year in the ocean. Thus, $T_{F}$ in all years.

(11) $T_{E}$ : Proportion of the year that escaped salmon and trout spent in coastal waters. As there has been no published information regarding the duration farmed salmon and trout escapees spend in coastal waters, we conservatively estimated that the duration was 6 mo per year $\left(T_{F}=0.5\right)$, which assumed that escape events occur evenly throughout the year. 
(12) $T_{W S}$ : Proportion of the year that returning wild salmon spend in coastal waters. Estimated at $16 \mathrm{~d}$ per year $\left(T_{W S}=0.044\right)$, as per Karlsen et al. (2017).

(13) $T_{W T}$ : Proportion of the year that wild sea trout spend in coastal waters. Trout smolts typically leave rivers in spring, and post-smolts may remain at sea during summer and return to freshwater over winter (Thorstad et al. 2016). Adults spend summers at sea and winters in freshwater, but some can remain at sea until they later return to freshwater for spawning. Therefore, we assumed that, on average, wild sea trout spend 6 mo of the year in coastal waters $\left(T_{W T}=0.5\right)$.

To calculate the proportion of the total host population represented by farmed fish in each year, we divided the number of salmonids in farms by the estimated total number of salmonids in the environment (farmed, wild and escapee salmon and trout) according to the following equation:

$$
P_{L}=\frac{H_{F} L_{F} T_{F}}{H_{F} L_{F} T_{F}+\left(H_{E S}+H_{E T}\right)+L_{E} T_{E}+H_{W S} L_{W S}+H_{W T} L_{W T} T_{W T}}
$$

To calculate the proportion of the reproductive lice population that is on farmed hosts, we factored in data on mean lice abundance per fish, and we weighted these numbers by the proportion of time infected hosts spend in coastal waters in any given year. Our proportion is, thus, an estimate of the likely proportional contribution that farmed fish make to future infestation pressure:

$$
P_{H}=\frac{H_{F}}{H_{F}+H_{E S}+H_{E T}+H_{W S}+H_{W T}}
$$

The calculation of $P_{L}$ assumes that adult female lice on farmed and wild salmonids produce the same number of larvae and that larvae produced by adult female lice on farmed and wild salmonids have the same probability of contributing to future infestation pressure. This assumption will result in a slight underestimation of the importance of farmed hosts if a high density of hosts and conspecifics at farms increases mate-finding success and facilitates higher reproductive output (e.g. Mennerat et al. 2017) or will overestimate their importance if regular lice control by farmers can maintain low infestation densities and reduce mate availability. To correct for differences in fertility based on mate availability (essentially an Allee effect, Krkošek et al. 2012), we used predictions from mate limitation models for farmed salmon (Stormoen et al. 2013) and wild sea trout (Murray 2002) to estimate the proportion of mated (i.e. ovigerous) adult female salmon lice based on the mean infestation density for each year. The proportional contribution of farms to lice reproduction was also calculated taking this effect into account, yielding $P_{L O}$ (the $\mathrm{O}$ for ovigerous adult female salmon lice). This alternative measure was calculated as for $P_{L}$ but with $L$ terms each multiplied by the predicted proportion of ovigerous females given the annual mean lice density of the host population. We are not aware of equivalent models for wild Atlantic salmon or escaped farmed salmon, so we used the sea trout model (Murray 2002) for all salmonids in the wild.

Some of our variables are uncertain, particularly those related to abundance and residency of wild salmonids (including farm escapees). To assess the sensitivity of the model to changes in these parameters, we recalculated $P_{L}$ and $P_{L O}$ with each of the following parameters increased by high but conceivable amounts to increase the importance of wild salmonids for salmon lice populations:

(1) $T_{E}$ : Escaped salmon may be more likely to remain in coastal waters than wild salmon. We tested the effect of increasing $T_{E}$ from 0.5 to 0.75 .

(2) $H_{E S}$ and $H_{E T}$ : The literature suggests that actual numbers of escapees are 2 to 4 times higher than reported. We tested the effect of multiplying reported escapes by 4 instead of 3 .

(3) $H_{W S}$ : Some proportion of non-returning wild salmon is likely present in the coastal zone. We tested the effect of doubling estimates for $H_{W S}$ to account for such individuals.

(4) $T_{W S}$ : Based on the available literature, we assumed that wild salmon spend the majority of their time at sea. We tested the effect of increasing $T_{W S}$ from 0.044 to 0.5 .

(5) $H_{W T}$ : Sea trout abundance is poorly understood and likely fluctuates slightly year to year. We tested the effect of increasing this estimate by $50 \%$ to 1.5 million.

(6) $T_{W T}$ : Sea trout use both coastal and offshore environments, but the proportion of time spent in each is uncertain. We tested the effect of increasing $T_{W T}$ to 0.75 .

We first adjusted each of these parameters sequentially to assess the sensitivity of the model to each one and then re-ran the model with all adjustments simultaneously to show the outcome of a severe underestimate of the contribution of lice on wild salmonids.

\section{RESULTS}

The number of farmed salmonids increased most years from 1998 to 2017 (Fig. 1A). The number of salmon and trout in the wild either declined or 

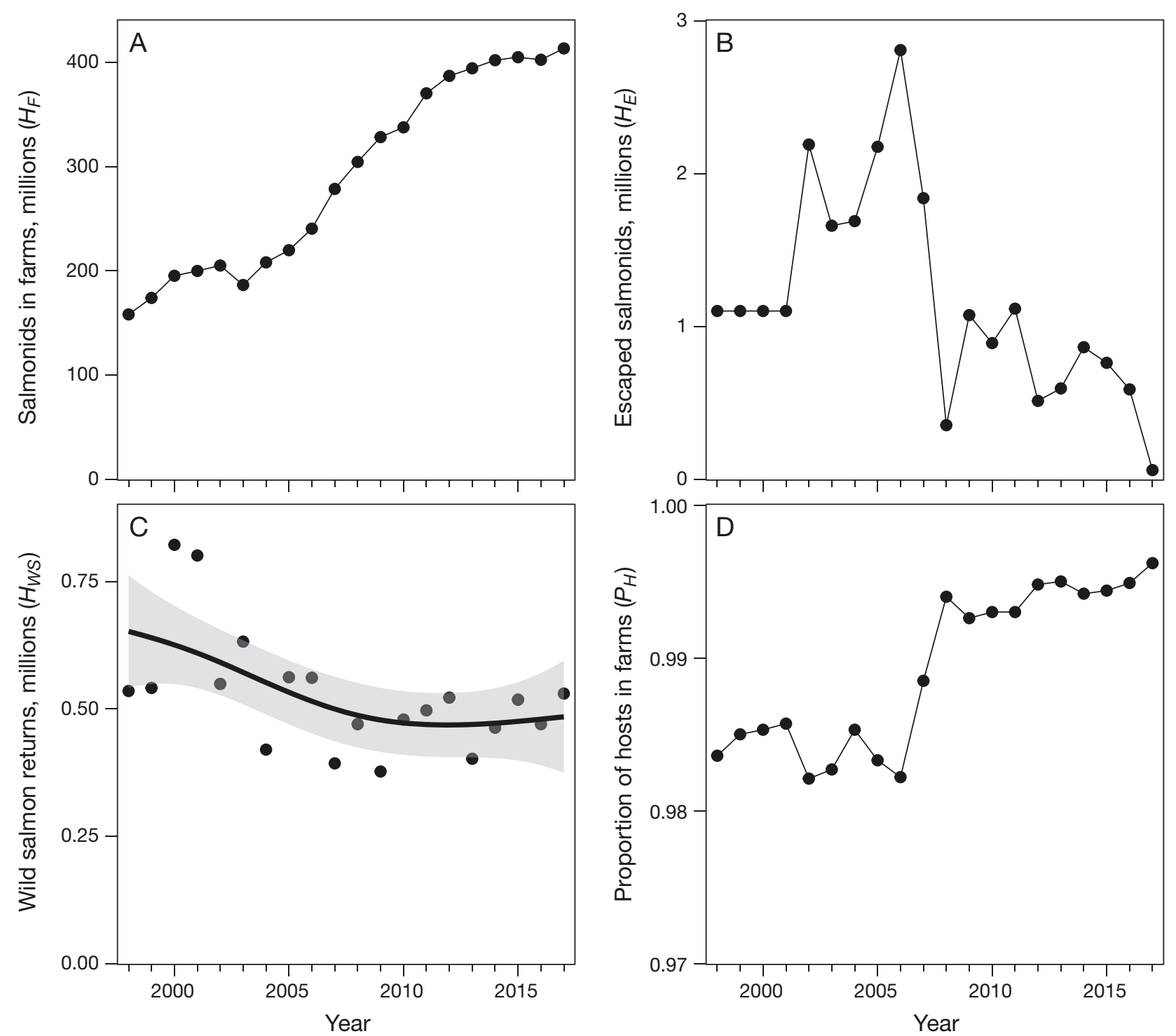

Fig. 1. Temporal trends in host availability for salmon lice in Norwegian coastal waters: (A) salmonids in farms, (B) escaped salmonids (reports multiplied by a factor of 3 to account for systemic underreporting), (C) wild salmon returns plotted with a generalised additive model fit and $95 \%$ CIs and (D) relative availability of salmonid hosts in farms vs. in the wild. Wild salmonid population includes farm escapees

remained stable over the same period, with the number of farm escapees peaking in 2006 before declining sharply (Fig. 1B) and wild salmon returns peaking in 2000 to 2001 before declining slightly and apparently stabilising around $500000 \mathrm{yr}^{-1}$ (Fig. 1C). Together, these trends have caused the relative host availability of farmed vs. wild salmonids to increase throughout 1998 to 2017 (Fig. 1D), and by 2017, farmed salmonids accounted for the vast majority $\left(P_{H}=0.996\right)$ of available hosts for salmon lice in the Norwegian coastal zone. From 2013 to 2017, farmed salmonids outnumbered wild salmonids (sea trout and returning salmon) by 267-281:1.
Mean lice infestation densities on both farmed and wild fish fluctuate considerably year to year but have generally declined over time (Fig. 2A-C). Despite this variation, the proportion of lice emanating from farms has been consistently high (2010-2017: $P_{L}=$ 0.97-0.99; Fig. 3). In other words, hosts in farms have accounted for $>97 \%$ of all adult female salmon lice in the Norwegian coastal zone for each year since 2010, while in 2017, we estimate that $99.1 \%$ of adult female salmon lice were in farms (Fig. 3). The number of lice per host tends to be lower on farmed salmonids, and limiting the model to ovigerous adult female lice slightly reduces the relative importance 


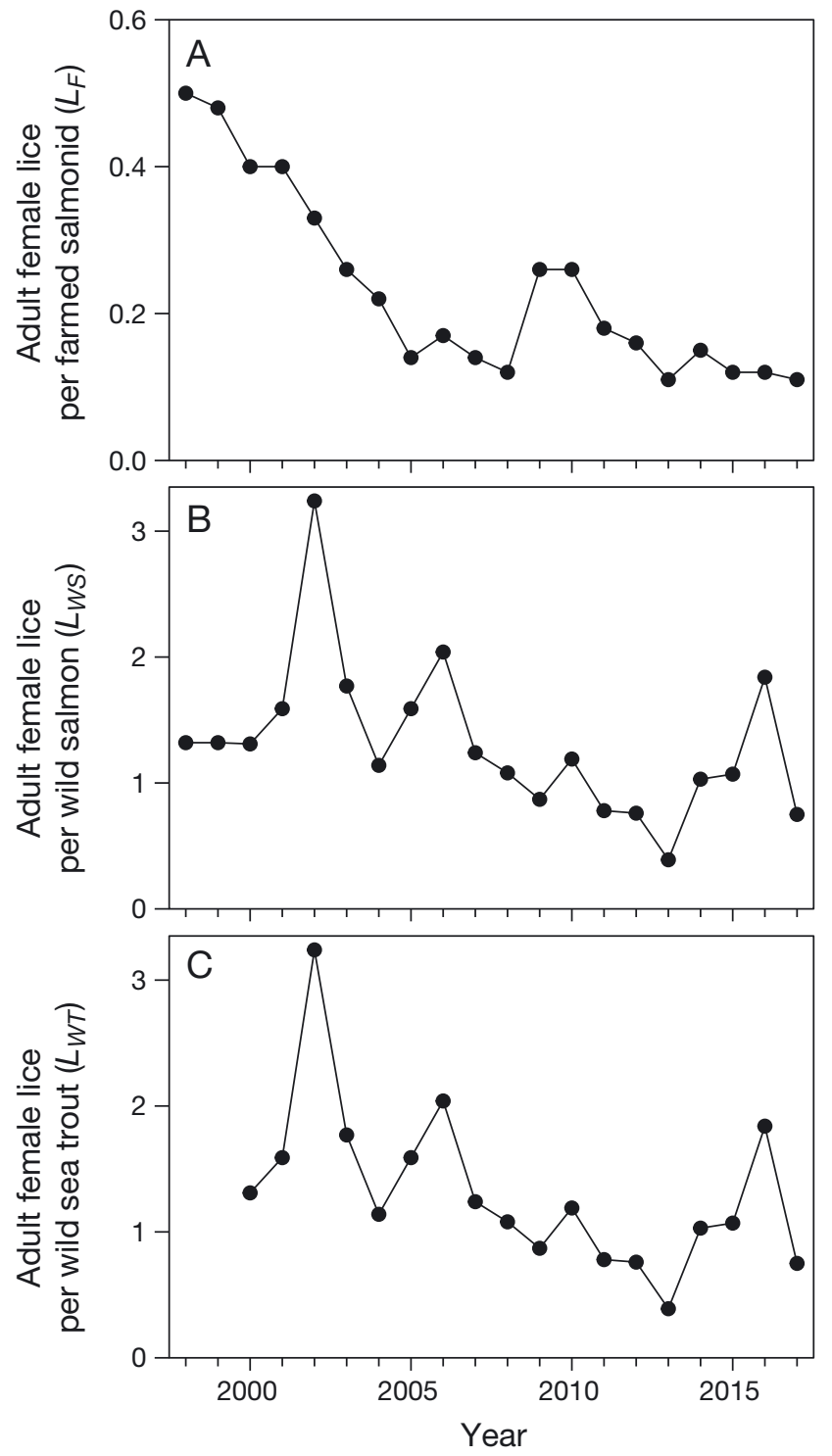

Fig. 2. Temporal trends in adult female salmon lice infestation density on (A) farmed salmon, (B) wild salmon and (C) wild sea trout

of farmed hosts in recent years, but the effect is qualitatively unchanged (in 2017, $P_{L O}=0.98$; Fig. 3)

Of the 6 parameters that were informed by uncertain data, the model was most sensitive to adjustments to $T_{W S}, H_{W T}$ and $T_{W T}$ (Table 1). These are parameters that describe the availability of wild salmon and sea trout hosts in the Norwegian coastal zone. However, none of these parameters, when adjusted in isolation, caused $P_{L}$ to fall below 0.96 in 2017 (Table 1; Fig. 3). Adjusting all the parameters simultaneously resulted in a lower $P_{L}$, but farmed salmon were still the dominant source of new lice $\left(P_{L}=0.92\right.$ : Table 1 ; Fig. 3$)$. Findings were qualita-

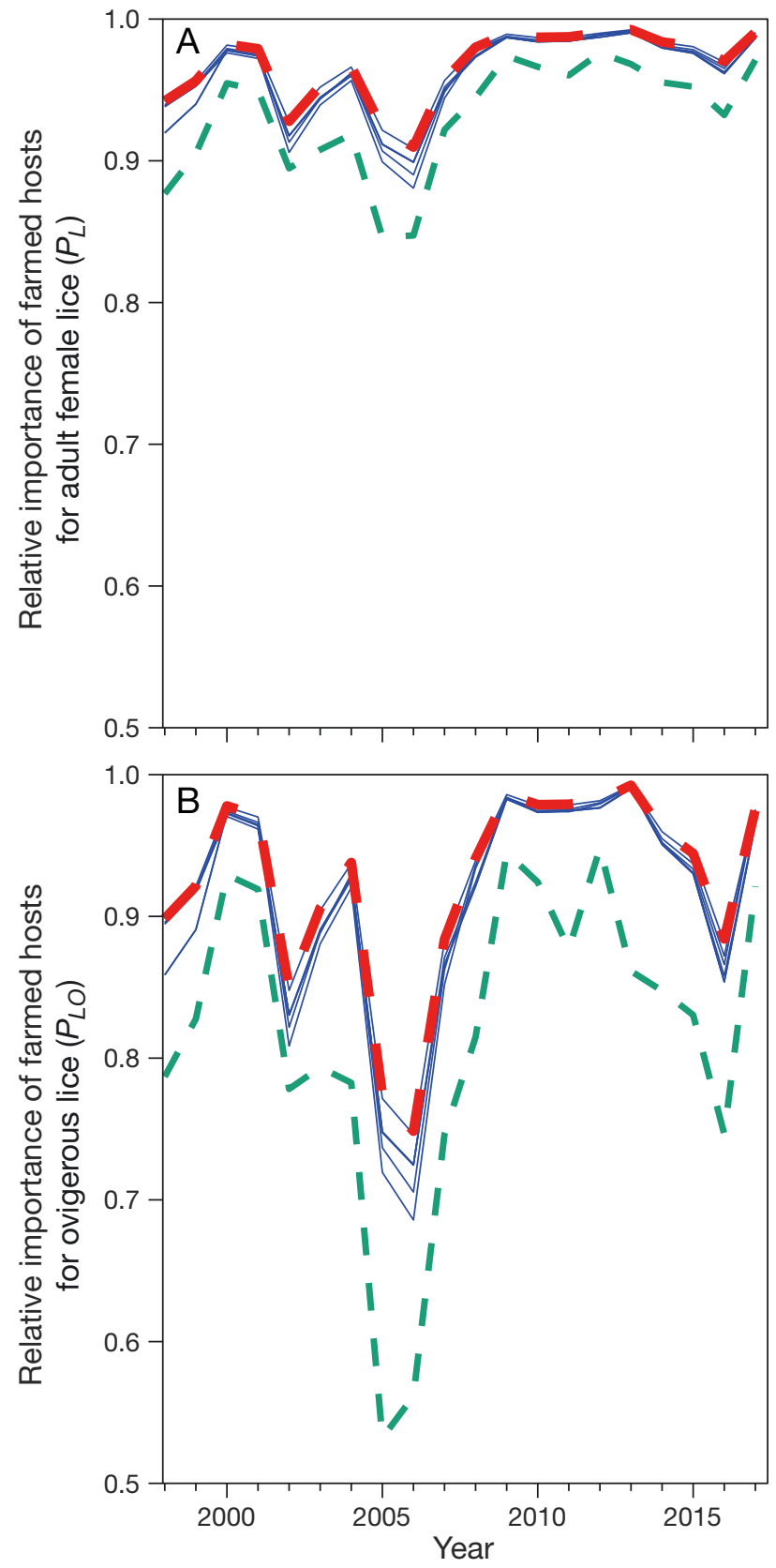

Fig. 3. Temporal trends in relative importance of farmed and wild salmonid hosts for adult female salmon lice: (A) all adult females and (B) mated (ovigerous) adult females only. Lines show proportional contributions based on (1) the best estimate of the number of hosts in farms per host in the wild (thick red dashed line), (2) adjustments for each of 6 uncertain parameters relating to wild host availability (grey solid lines) and (3) the worst-case underestimate of wild host availability (green dashed line)

tively similar for $P_{L O}$ (Table 1; Fig. 3). Together, this indicates that the model is highly robust to uncertainty around these parameters or fluctuations in abundance of wild salmon and sea trout. 
Table 1. Outcomes of a sensitivity analysis considering 6 uncertain parameters that relate to the availability of wild salmonid hosts in 2017 . Using our best estimates for each of these parameters indicates that $99.1 \%$ of adult female salmon lice $\left(P_{L}=0.991\right)$ and $97.6 \%$ of ovigerous females $\left(P_{L O}=0.976\right)$ were within salmon farms in 2017 . However, $P_{L}$ and $P_{L O}$ are both reduced under each of the following scenarios: (1) Escaped salmon are more likely to remain in coastal waters than wild salmon; (2) Rates of escape by farmed salmonids are higher than our best estimate; (3) More non-returning wild salmon are present in the coastal zone than our best estimate; (4) Wild salmon spend more time in coastal waters than our best estimate; (5) Sea trout abundance is higher than our best estimate; (6) Sea trout spend more time in the coastal zone than our best estimate; All: Scenarios 1-6 applied simultaneously

\begin{tabular}{|lccccc|}
\hline Scenario & $\begin{array}{c}\text { Affected } \\
\text { parameter }\end{array}$ & $\begin{array}{c}\text { Best } \\
\text { estimate }\end{array}$ & $\begin{array}{c}\text { Alternative } \\
\text { estimate }\end{array}$ & $\begin{array}{c}P_{L} \text { based on } \\
\text { alternative estimate }\end{array}$ & $\begin{array}{c}P_{L O} \text { based on } \\
\text { alternative estimate }\end{array}$ \\
\hline 1 & $T_{E}$ & 0.5 & 0.75 & 0.990 & 0.975 \\
2 & $H_{E}$ & 45000 & 60000 & 0.990 & 0.975 \\
3 & $H_{W S}$ & 530000 & 1060000 & 0.990 & 0.975 \\
4 & $T_{W S}$ & 0.044 & 0.5 & 0.987 & 0.965 \\
5 & $H_{W T}$ & 1000000 & 1500000 & 0.986 & 0.965 \\
6 & $T_{W T}$ & 0.5 & 0.75 & 0.986 & 0.921 \\
All & All & All & All & 0.971 & \\
\hline
\end{tabular}

\section{DISCUSSION}

\subsection{Overwhelming importance of farmed hosts for salmon lice}

We estimate that the vast majority (99.1\%) of adult female salmon lice in Norwegian coastal waters occur on farmed salmonids. Farmed hosts are clearly the reproductive engine for the lice population. While the model includes several data-poor parameters related to the abundance and distribution of wild salmonids, the abundance of farmed hosts is now so large that the model is highly robust to changes in the estimated population size of wild hosts. According to our most conservative estimate, which greatly increased the number of wild hosts in the coastal zone, farmed salmon still hosted $97.1 \%$ of adult female lice and $92.1 \%$ of ovigerous adult female lice in 2017 . For at least the past 2 decades, farmed hosts have driven lice abundance with negligible contributions from wild hosts.

\subsection{Model assumptions and uncertainty}

For the variables informed by uncertain data, and other model variables, we used conservative values which would have overestimated the contribution of lice on wild salmonids to overall lice abundance. Evidence suggests that some of these variables likely have lower values which would diminish the contribution of lice on wild salmonids and thus increase the estimate of $P_{L}$. As the model was sensitive to $T_{W S}$, it is worth exploring the estimate used, in addition to $H_{W S}$ (number of wild salmon returns in a given year), which was not sensitivity tested as yearly estimates were available but behaves in a similar way in the model as $H_{W T}$. The Norway scale values used for $H_{W S}$ and $H_{W T}$ assumed that lice infesting returning salmon and sea trout contribute equally to generating salmon lice, regardless of where these fish occur geographically. We estimate that only $\sim 55 \%$ of the total number of salmon that return to rivers in Norway each year do so to areas where intensive salmon farming occurs (intensive salmon farming areas: western Norway $=40000$ returnees, middle Norway $=180000$ and half of northern Norway $=64500$ ), with $45 \%$ returning to areas with little or no salmon farming (southern Norway $=124000$, half of northern Norway $=64$ 500, Tana River $=39000$; Thorstad et al. 2020). Sea trout population numbers are far less certain but are believed to be in long-term decline with only $20 \%$ of 430 populations classified as being in good condition, $31 \%$ in moderate condition and $48 \%$ in poor condition, largely due to the negative impacts of salmon lice infestations (Thorstad et al. 2019). Our national estimate would also include many individuals in coastal areas where no salmon farming occurs in southern and northern Norway. Wild salmon and sea trout populations in areas where salmon farming is absent or limited are less likely to become infected with lice than intensive farming regions, and thus the contribution of lice that infest them to the overall lice population will be relatively small. This leads to a broader point that the model operates at nation scale, using national level averages. Refining the model to address regional variability across many of the variables would likely reveal areas where estimates of $P_{L}$ are higher and lower than the nationwide average of 0.97 to 0.99 from 2010 to 2017 . 


\subsection{Implications for salmon lice ecology and evolution}

Evidence exists that the farm environment has already driven lice evolution (e.g. Mennerat et al. 2012, Ugelvik et al. 2017), and our results suggest this process will continue with little mitigation provided by gene flow from lice on wild hosts. Salmon farming in Norway is now over $40 \mathrm{yr}$ old. As 8 to 10 lice generations are possible per year, depending on temperatures (Samsing et al. 2016, Hamre et al. 2019), there have been up to 300 generations of salmon lice since farming began. Lice of all life stages face novel conditions and selection pressures at farms, including a high density and abundance of both hosts and conspecifics, along with periodic human intervention in the form of lice management (preventative or post-infestation delousing) and harvesting of their salmonid hosts. Coates et al. (2021) assessed the potential for salmon lice to adapt to the main prevention and control methods (chemotherapeutants, mechanical and thermal treatments, cleaner fish, freshwater treatments, depth-based preventions [e.g. skirts and snorkels] and selective breeding). Lice have evolved resistance to at least 4 of 5 chemical therapeutants (Aaen et al. 2015, Myhre Jensen et al. 2020), and while evidence is incomplete for the other louse control methods, Coates et al. (2021) concluded that the evolution of resistance to non-chemical methods is a strong possibility given the variation that exists in and between louse populations (Jacobs et al. 2018) on which non-chemical selection pressures could act and that this variation may have a genetic basis.

In other parts of the world, wild hosts constitute a much higher proportion of the total host population. In these areas, we can expect adaptation by lice to farmed conditions to be slowed through a constant flow of farm-maladapted genes from the wild population (Kreitzman et al. 2018). This gene flow is an evosystem service provided by a robust wild population of hosts. Our data show that the situation in Norway is vastly different: here, the size of the industry means the farmed population numerically dominates the wild population. Maladaptive gene flow in this case will be outwards, towards the louse population held on wild salmonids.

In this system, wild salmonids may still be influential, not as a reservoir but as vectors that boost lice population connectivity between farming regions. Indeed, where farms are oceanographically distant from upstream farms (i.e. beyond the planktonic dispersal distance of a single cohort of larval lice), highly mobile wild hosts may act as a vector that facilitates the spread of lice and genes that confer resistance to control measures throughout a farming network. With infectivity of salmon lice copepodids almost negligible after $14 \mathrm{~d}$ at $10^{\circ} \mathrm{C}$ (Skern-Mauritzen et al. 2020), there are likely many sites that rarely receive infestation pressure directly from upstream farms. So-called firebreaks, or areas of no farming that disrupt dispersal pathways, targeted to decrease connectivity in planktonic lice dispersal pathways are projected to provide benefits by slowing the dispersal of genes that confer resistance to specific treatments and reducing the pool of available infective stages to create first infestations after stocking (Samsing et al. 2019). High connectivity of salmon lice populations facilitated by wild hosts could weaken the effectiveness of firebreaks and the advantages they confer. Given this situation, it is interesting to consider the selection pressures that act on lice attached to farmed hosts and how this may affect lice fitness on wild hosts.

\subsubsection{Life history traits}

Evolutionary theory predicts that host-parasite systems with high parasite transmission rates will select for high virulence; where there is a high availability of new hosts, parasite fitness is maximised by early maturation and high fecundity even if it damages the host. Fish farming creates such conditions (Nowak 2007, Mennerat et al. 2010). In contrast, salmon lice that infest wild hosts can have a relatively long lifespan before the host dies or returns to freshwater. Furthermore, lice on wild hosts may sometimes have little choice but to await the arrival of a potential mate to the same host, as it is inherently risky to attempt to switch hosts when hosts are infrequent. Conversely, farming conditions favour a rapid life cycle, driven by (1) an abundance of mates; (2) high host availability, which could facilitate host switching as adult lice and increase the likelihood of offspring finding a host; and (3) the need to reproduce before the farmer delouses or harvests. Individuals that invest heavily in reproduction early in life (even at the expense of somatic growth) are more likely to produce offspring before delousing or harvesting occurs.

Common garden experiments demonstrate that salmon farming has altered the virulence and life history of salmon lice. Lice strains collected from farmed salmon in areas with intensive aquaculture caused more severe skin damage, achieved higher infestation densities and produced more eggs in their first batch (and fewer in later batches) than strains collected 
from wild hosts in unfarmed locations (Mennerat et al. 2017, Ugelvik et al. 2017). These differences were observed after lice strains were reared in the laboratory for at least 3 generations, pointing to underlying genetic variation in virulence and reproduction.

\subsubsection{Host availability and host-finding traits}

Louse larvae that do not find and attach to a host do not reproduce; therefore, there should be strong selection pressure on traits that affect encounter or attachment success. To the extent that such traits are heritable, rapid evolution likely drives responses to changes in the availability and distribution of hosts from the expansion of farming. This has clear implications for the evolutionary ecology of lice-salmon interactions. Farming increases the abundance of potential hosts, which could conceivably dampen or alter selection pressure on host-finding traits. However, farmers may also intervene with barriers to infestation, including technologies to prevent encounters between lice and hosts in the surface layers where lice are most common, such as snorkel cages (Geitung et al. 2019) and skirts (Grøntvedt et al. 2018, Stien et al. 2018), and behavioural manipulation of swimming depth using deep lights and feeding (Frenzl et al. 2014). Swimming depth of the infectious copepodid larval stage varies among families (Coates et al. 2020) and may have a genetic basis. If the vertical distribution of lice is influenced by heritable traits, then the increasing mean depth of available hosts could drive the evolution of lice larvae with deeper distributions. Intriguingly, this could be a benefit for wild salmon if the widespread adoption of deeper farming leads to a gradual decoupling of the preferred shallow swimming depths of outmigrating wild salmon smolts (Plantalech Manel-la et al. 2009) and sea trout in coastal waters (Rikardsen et al. 2007) and salmon lice, reducing the infestation pressure for wild salmonids.

\subsubsection{No wild refuge to slow the development of treatment resistance}

While effective delousing reduces life expectancy for lice and thus selects for faster life history and increased virulence, treatments that allow some survivorship will also drive the evolution of treatment resistance. The rapid evolution of treatment resistance is a recurring story in human health and intensive agriculture (e.g. antibiotics: Raymond 2019).
Salmon aquaculture in Norway is similarly vulnerable because the number of farmed salmon is far greater than the number of wild salmon, such that the main source for re-infestation comes from hydrodynamically connected farms. Frequent parasite treatments apply constant selection pressure on traits for resistance, and the vast majority of the lice population is exposed to the selection pressure from these treatments (Overton et al. 2019, Coates et al. 2021).

Genes that encode resistance to chemotherapeutants are already common in the salmon lice population in the Atlantic. Resistance to the treatments emamectin benzoate and azamethiphos each emerged at single point sources, before rapidly spreading across the North Atlantic (Besnier et al. 2014, Kaur et al. 2016, Fjørtoft et al. 2020). This situation contrasts sharply with the common use of emamectin benzoate on the Pacific coast of North America. Emamectin benzoate has remained highly effective, at least until very recently (Messmer et al. 2018), presumably because there was enough gene flow from lice on abundant wild hosts that are not exposed to the treatment (Kreitzman et al. 2017). As a simple comparison of farmed and wild salmonid numbers on the Canadian-US west coast, Kreitzman et al. (2017) compared wild salmonid capture and aquaculture production to show wild salmonids were 5 times more abundant. Using an agent-based model to predict how important wild salmon population size is as a wild refugium to the evolution of resistance of salmon lice to chemotherapeutants, McEwan et al. (2015) revealed that while equal numbers of farmed and wild salmon tempered the evolution of resistance, ratios of 10:1 farmed to wild salmon resulted in high levels of evolved resistance. Norway is far beyond this level (267-281:1 farmed to wild from 2013 to 2017), and other major farming regions in the Atlantic (e.g. Scotland and the east coast of North America) likely also exceed the 10:1 farmed to wild salmon threshold for high levels of evolved resistance.

Treatment resistance can be costly for the farming industry, as stock must be harvested early or culled when they cannot be treated, and resistance is not limited to pharmaceuticals: there are now reports of farmers needing to use higher concentrations in hydrogen peroxide baths, higher temperatures or longer durations in thermal delousing systems, and longer durations in freshwater baths. Each of these traits is thought to have a heritable basis (Helgesen et al. 2015, Ljungfeldt et al. 2017, Treasurer et al. 2000). 


\subsection{Implications for salmon lice dispersal modelling}

The Norwegian salmon lice dispersal model is a spatially explicit biophysical model combining a hydrodynamic model and particle-tracking module (Asplin et al. 2014, Johnsen et al. 2014, Myksvoll et al. 2018). Larval supply (rate of hatching) is calculated from weekly reports of the number of farmed fish, adult female lice per fish and water temperature at each site (Johnsen et al. 2020). The likely dispersal of released larval particles is modelled primarily using the horizontal current component coupled with aging and mortality of larvae. Managers assess the model outputs and sample wild fish for ground truthing of model predictions. Modelled and observed infestation data are then reported to the Norwegian Food Safety Authority. At the end of each season, the model is re-run with updated data and the outputs used to inform the annual risk assessment of salmon lice infestation pressure on wild salmonids, which in turn assists the Norwegian Ministry of Trade and Fisheries in setting farmed biomass limits for the following year across each of Norway's 13 production zones (the traffic light system: Norwegian Ministry of Trade and Fisheries 2017). The predictive methodology has been criticised for its assumption that farmed salmon are the overriding driver of larval supply and that lice derived from wild salmonids are not considered. The findings from our model indicate that accounting for releases of larvae from wild hosts, even if possible, would not provide meaningful improvement to predictions of infestation pressure.

\subsection{Conclusions}

Farmed salmonids are of overwhelming importance for the ecology and evolution of salmon lice in Norway. In 2017, salmonids in farms accounted for $99.6 \%$ of available hosts and $99.3 \%$ of adult female salmon lice in Norwegian coastal waters. As such, we suggest that modelled estimates of infestation pressure can safely be informed by data on lice populations in farms alone. Moreover, the wild salmonid population is unlikely to function as a meaningful refuge from selection pressures in the sea cage environment and will not slow the evolution of resistance to lice management strategies applied within farms. Rather, wild salmon are likely to be parasitised by lice that are increasingly well adapted to farm conditions. Whether this will result in a lower or higher impact on wild salmon remains unclear. Through dispersal, however, wild fish may still connect the broader lice population and ensure gene flow. The extent to which this will be true will depend on how effectively farm-adapted lice can infest and be dispersed by wild fish, an outcome difficult to predict as the evolutionary trajectory of salmon lice becomes increasingly attuned to their farmed hosts.

\section{LITERATURE CITED}

Aaen SM, Helgesen KO, Bakke MJ, Kaur K, Horsberg TE (2015) Drug resistance in sea lice: a threat to salmonid aquaculture. Trends Parasitol 31:72-81

Asplin L, Boxaspen KK, Sandvik AD (2004) Modelled distribution of salmon lice in a Norwegian fjord. ICES CM 2004/P:11

Asplin L, Johnsen IA, Sandvik AD, Albretsen J, Sundfjord V, Aure J, Boxaspen KK (2014) Dispersion of salmon lice in the Hardangerfjord. Mar Biol Res 10:216-225

*Barber I (2007) Parasites, behaviour and welfare in fish. Appl Anim Behav Sci 104:251-264

Barrett LT, Oppedal F, Robinson N, Dempster T (2020) Prevention not cure: a review of methods to avoid sea lice infestations in salmon aquaculture. Rev Aquacult 12:2527-2543

* Besnier F, Kent M, Skern-Mauritzen R, Lien S and others (2014) Human-induced evolution caught in action: SNParray reveals rapid amphi-Atlantic spread of pesticide resistance in the salmon ecotoparasite Lepeophtheirus salmonis. BMC Genomics 15:937

Bjørn PA, Finstad B, Kristoffersen R (2001) Registreringer av lakselus på laks, sjøørret og sjørøye i 2000. NINA Oppdragsmelding 698. NINA, Trondheim (in Norwegian with English Abstract)

Bjørn PA, Finstad B, Kristoffersen R (2002) Registreringer av lakselus på laks, sjøørret og sjørøye i 2001. NINA Oppdragsmelding 737. NINA, Trondheim (in Norwegian with English Abstract)

Bjørn PA, Finstad B, Kristoffersen R (2003) Registreringer av lakselus på laks, sjøørret og sjørøye i 2002. NINA Oppdragsmelding 789. NINA, Trondheim (in Norwegian with English Abstract)

Bjørn PA, Finstad B, Kristoffersen R (2004) Registreringer av lakselus på laks, sjøørret og sjørøye i 2003. NINA Oppdragsmelding 853. NINA, Trondheim (in Norwegian with English Abstract)

Bjørn PA, Finstad B, Kristoffersen R (2005) Registreringer av lakselus på laks, sjøørret og sjørøye i 2004. NINA Rapport 60. http://hdl.handle.net/11250/2433428 (accessed 24 Nov 2020) (in Norwegian with English Abstract)

* Bjørn PA, Finstad B, Nilsen R, Skaala Ø, Øverland T (2007) Registreringer av lakselus på laks, sjøørret og sjørøye i 2006. NINA Report 250. http://hdl.handle.net/11250/244 3877 (accessed 24 Nov 2020) (in Norwegian with English Abstract)

Bjørn PA, Finstad B, Nilsen R, Asplin L and others (2008) Nasjonal overvåkning av lakselusinfeksjon på ville bestander av laks, sjøørret og sjørøye I forbindelse med nasjonale laksevassdrag og laksefjorder. NINA Rapport 377. http://hdl.handle.net/11250/2473726 (accessed 24 Nov 2020) (in Norwegian with English Abstract)

Bjørn PA, Finstad B, Nilsen R, Uglem I and others (2009) Nasjonal lakselusovervåkning 2008 på ville bestander av laks, sjøørret og sjørøye langs Norskekysten samt i forbindelse med evaluering av nasjonale laksevassdrag og laksefjorder. NINA Rapport 447. http://hdl.handle.net/ 
11250/2396001 (accessed 24 Nov 2020) (in Norwegian with English Abstract)

Bjørn PA, Finstad B, Nilsen R, Uglem I, Asplin L, Skaala Ø Hvidsten NA (2010) Nasjonal lakselusovervåkning 2009 på ville bestander av laks, sjøørret og sjørøye langs Norskekysten samt i forbindelse med evaluering av nasjonale laksevassdrag og laksefjorder. NINA Rapport 547. http://hdl.handle.net/11250/2566980 (accessed 24 Nov 2020) (in Norwegian with English Abstract)

Bondad-Reantaso MG, Subasinghe RP, Arthur JR, Ogawa K and others (2005) Disease and health management in Asian aquaculture. Vet Parasitol 132:249-272

Bouwmeester MM, Anouk Goedknegt M, Poulin R, Thieltges TW (2021) Collateral diseases: aquaculture impacts on wildlife infections. J Appl Ecol 58:453-464

Coates A, Phillips BL, Oppedal F, Bui S, Overton K, Dempster T (2020) Parasites under pressure: salmon lice have the capacity to adapt to depth-based preventions in aquaculture. Int J Parasitol 50:865-872

Coates A, Phillips B, Bui S, Oppedal F, Robinson N, Dempster T (2021) Evolution of salmon lice in response to management strategies: a review. Rev Aquacult, doi:10.1111/ raq. 12528

* Duarte CM, Marbá N, Holmer M (2007) Rapid domestication of marine species. Science 316:382-383

FAO (2020) The state of world fisheries and aquaculture 2020. FAO, Rome www.fao.org/documents/card/en/c/ca 9229en (accessed 19 Oct 2020)

Fjørtoft HB, Nilsen F, Besnier F, Espedal PG and others (2020) Aquaculture-driven evolution: distribution of pyrethroid resistance in the salmon louse throughout the North Atlantic in the years 2000-2017. ICES J Mar Sci 77:1806-1815

Frenzl B, Stien LH, Cockerill D, Oppedal F and others (2014) Manipulation of farmed Atlantic salmon swimming behaviour through the adjustment of lighting and feeding regimes as a tool for salmon lice control. Aquaculture 424-425:183-188

Geitung L, Oppedal F, Stien LH, Dempster T, Karlsbakka E, Nola V, Wright DW (2019) Snorkel sea-cage technology decreases salmon lice infestation by $75 \%$ in a full-cycle commercial test. Int J Parasitol 49:843-846

Grimnes A, Finstad B, Bjørn PA (1999) Registreringer av lakselus på laks, sjøørret og sjørøye i 1998. NINA Oppdragsmelding 579. https://www.nina.no/archive/nina/ PppBasePdf/oppdragsmelding/579.pdf (in Norwegian with English Abstract)

Grimnes A, Finstad B, Bjørn PA (2000) Registreringer av lakselus på laks, sjøørret og sjørøye i 1999. NINA Oppdragsmelding 634. https://www.nina.no/archive/nina/ PppBasePdf/oppdragsmelding/634.pdf (in Norwegian with English Abstract)

Grøntvedt RN, Kristoffersen AB, Jansen PA, Grontvedt RN, Kristoffersen AB, Jansen PA (2018) Reduced exposure of farmed salmon to salmon louse (Lepeophtheirus salmonis L.) infestation by use of plankton nets: estimating the shielding effect. Aquaculture 495:865-872

Hamre LA, Bui S, Oppedal F, Skern-Mauritzen R, Dalvin S (2019) Development of the salmon louse Lepeophtheirus salmonis parasitic stages in temperatures ranging from 3 to $24^{\circ} \mathrm{C}$. Aquacult Environ Interact 11:429-443

Helgesen KO, Romstad H, Aaen SM, Horsberg TE (2015) First report of reduced sensitivity towards hydrogen peroxide found in the salmon louse Lepeophtheirus salmonis in Norway. Aquacult Rep 1:37-42
Heuch PA, Mo TA (2001) A model of salmon louse production in Norway: effects of increasing salmon production and public management measures. Dis Aquat Org 45: $145-152$

Jacobs A, De Noia M, Praebel K, Kanstad-Hanssen $\varnothing$ and others (2018) Genetic fingerprinting of salmon louse (Lepeophtheirus salmonis) populations in the North-East Atlantic using a random forest classification approach. Sci Rep 8:1203

*Johnsen IA, Fiksen Ø, Sandvik AD, Asplin L (2014) Vertical salmon lice behaviour as a response to environmental conditions and its influence on regional dispersion in a fjord system. Aquacult Environ Interact 5:127-141

Johnsen IA, Stien LH, Sandvik AD, Asplin L, Oppedal F (2020) Optimal estimation of lice release from aquaculture based on ambient temperatures. Aquacult Environ Interact 12:179-191

Johnsen IA, Harvey A, Sævik PN, Sandvik AD and others (2021) Salmon lice-induced mortality of Atlantic salmon during post-smolt migration in Norway. ICES J Mar Sci 78:142-154

Karlsen Ø, Finstad B, Ugedal O, Svåsand T (2017) Kunnskapsstatus som grunnlag for kapasitetsjustering innen produksjons-områder basert på lakselus som indikator. Rapport fra havforskningen nr. 14-2016. www.regjeringen.no/no/dokumenter/kunnskapsstatus-som-grunnlagfor-kapasitetsjustering-innen-produksjons-omraderbasert-pa-lakselus-som-indikator/id2484235/

Kaur K, Jansen PA, Aspehaug VT, Horsberg TE (2016) Phe362Tyr in AChE: a major factor responsible for azamethiphos resistance in Lepeophtheirus salmonis in Norway. PLOS ONE 11:e0149264

Kennedy DA, Kurath G, Brito IL, Purcell MK, Read AF, Winton JR, Wargo AR (2016) Potential drivers of virulence evolution in aquaculture. Evol Appl 9:344-354

*Kent ML (2000) Marine netpen farming leads to infections with some unusual parasites. Int J Parasitol 30:321-326

Klemetsen A, Amundsen PA, Dempson JB, Jonsson B, Jonsson N, O'Connell MF, Mortensen E (2003) Atlantic salmon Salmo salar L., brown trout Salmo trutta L. and Arctic charr Salvelinus alpinus (L.): a review of aspects of their life histories. Ecol Freshwat Fish 12:1-59

Kreitzman M, Ashander J, Driscoll J, Bateman AW, Chan KMA, Lewis MA, Krkosek M (2018) Wild salmon sustain the effectiveness of parasite control on salmon farms: conservation implications from an evolutionary ecosystem service. Conserv Lett 11:e12395

Krkošek M, Connors BM, Lewis MA, Poulin R (2012) Allee effects may slow the spread of parasites in a coastal marine ecosystem. Am Nat 179:401-412

Krkošek M, Revie CW, Gargan PG, Skilbrei OT, Finstad B, Todd CD (2013) Impact of parasites on salmon recruitment in the Northeast Atlantic Ocean. Proc R Soc B 280: 20122359

ㄴ Ljungfeldt LER, Quintela M, Besnier F, Nilsen F, Glover KA (2017) A pedigree-based experiment reveals variation in salinity and thermal tolerance in the salmon louse, Lepeophtheirus salmonis. Evol Appl 10:1007-1019

McEwan GF, Groner ML, Fast MD, Gettinby G, Revie CW (2015) Using agent-based modelling to predict the role of wild refugia in the evolution of resistance of sea lice to chemotherapeutants. PLOS ONE 10:e0139128

* Mennerat A, Nilsen F, Ebert D, Skorping A (2010) Intensive farming: evolutionary implications for parasites and pathogens. Evol Biol 37:59-67 
Mennerat A, Hamre LA, Ebert D, Nilsen F, Davidova M, Skorping A (2012) Life history and virulence are linked in the ectoparasitic salmon louse Lepeophtheirus salmonis. J Evol Biol 25:856-861

Mennerat A, Ugelvik MS, Jensen CH, Skorping A (2017) Invest more and die faster: the life history of a parasite on intensive farms. Evol Appl 10:890-896

Messmer AM, Leong JS, Rondeau EB, Mueller A and others (2018) A 200K SNP chip reveals a novel Pacific salmon louse genotype linked to differential efficacy of emamectin benzoate. Mar Genomics 40:45-57

Murray AG (2002) Using observed load distributions with a simple model to analyse the epidemiology of sea lice (Lepeophtheirus salmonis) on sea trout (Salmo trutta). Pest Manag Sci 58:585-594

Myhre Jensen E, Horsberg TE, Sevatdal S, Helgesen KO (2020) Trends in de-lousing of Norwegian farmed salmon from 2000-2019-Consumption of medicines, salmon louse resistance and non-medicinal control methods. PLOS ONE 15:e0240894

Myksvoll MS, Sandvik AD, Albretsen J, Asplin L and others (2018) Evaluation of a national operational salmon lice monitoring system - from physics to fish. PLOS ONE 13: e0201338

Norwegian Directorate of Fisheries (2020a) Sale 1994-2019. https://www.fiskeridir.no/English/Aquaculture/Statistics/ Atlantic-salmon-and-rainbow-trout (accessed 14 Oct 2020)

Norwegian Directorate of Fisheries (2020b) Rømmingsstatistikk. https://www.fiskeridir.no/Akvakultur/Tall-oganalyse/Roemmingsstatistikk (accessed 9 Jun 2021)

Norwegian Ministry of Trade and Fisheries (2012) Forskrift om bekjempelse av lakselus i akvakulturanlegg. https:// lovdata.no/dokument/SF/forskrift/2012-12-05-1140?q= lakselus (accessed 14 Oct 2020)

Norwegian Ministry of Trade and Fisheries (2017) Forskrift om produksjonsområder for akvakultur av matfisk i sjø av laks, ørret og regnbueørret (produksjonsområdeforskriften). https://lovdata.no/dokument/SF/forskrift/ 2017-01-16-61 (accessed 14 Oct 2020)

Nowak BF (2007) Parasitic diseases in marine cage culturean example of experimental evolution of parasites? Int J Parasitol 37:581-588

Overton K, Dempster T, Oppedal F, Kristiansen TS, Gismervik K, Stien LH (2019) Salmon lice treatments and salmon mortality in Norwegian aquaculture: a review. Rev Aquacult 11:1398-1417

Plantalech Manel-la N, Thorstad EB, Davidsen JG, Økland F, Sivertsgård R, Mckinley RS, Finstad B (2009) Vertical movements of Atlantic salmon post-smolts relative to measures of salinity and water temperature during the first phase of the marine migration. Fish Manag Ecol 16: 147-154

Raymond B (2019) Five rules for resistance management in the antibiotic apocalypse, a road map for integrated microbial management. Evol Appl 12:1079-1091

Rikardsen $\mathrm{AH}$, Diserud $\mathrm{OH}$, Elliott JM, Dempson JB, Sturlaugsson J, Jensen AJ (2007) The marine temperature and depth preferences of Arctic charr (Salvelinus alpinus) and sea trout (Salmo trutta), as recorded by data storage tags. Fish Oceanogr 16:436-447

Samsing F, Oppedal F, Dalvin S, Johnsen I, Vågseth T, Dempster T (2016) Salmon lice (Lepeophtheirus salmonis) development times, body size, and reproductive out-

Editorial responsibility: Kate S. Hutson,

Nelson, New Zealand

Reviewed by: 3 anonymous referees puts follow universal models of temperature dependence. Can J Fish Aquat Sci 73:1841-1851

* Samsing F, Johnsen I, Treml EA, Dempster T (2019) Identifying 'firebreaks' to fragment dispersal networks of a marine parasite. Int J Parasitol 49:277-286

Sandvik AD, Bjørn PA, Ådlandsvik B, Asplin L and others (2016) Toward a model-based prediction system for salmon lice infestation pressure. Aquacult Environ Interact 8:527-542

* Sandvik AD, Johnsen IA, Myksvoll MS, Sævik PN, Skogen MD (2020) Prediction of the salmon lice infestation pressure in a Norwegian fjord. ICES J Mar Sci 77:746-756

Serra-Llinares RM, Bjørn PA, Finstad B, Nilsen R, Asplin L (2016) Nearby farms are a source of lice for wild salmonids: a reply to Jansen et al. (2016). Aquacult Environ Interact 8:351-356

* Skarðhamar J, Albretsen J, Sandvik AD, Lien VS and others (2018) Modelled salmon lice dispersion and infestation patterns in a sub-arctic fjord. ICES J Mar Sci 75:1733-1747

* Skern-Mauritzen R, Sissener NH, Sandvik A, Meier S and others (2020) Parasite development affect dispersal dynamics; infectivity, activity and energetic status in cohorts of salmon louse copepodids. J Exp Mar Biol Ecol 530-531:151429

Skilbrei OT, Heino M, Svåsand T (2015) Using simulated escape events to assess the annual numbers and densities of escaped farmed Atlantic salmon of different life stages from farm sites in Norway. ICES J Mar Sci 72:670-685

* Stien LH, Lind MB, Oppedal F, Wright DW, Seternes T (2018) Skirts on salmon production cages reduced salmon lice infestations without affecting fish welfare. Aquaculture 490:281-287

* Stormoen M, Skjerve E, Aunsmo A (2013) Modelling salmon lice, Lepeophtheirus salmonis, reproduction on farmed Atlantic salmon, Salmo salar L. J Fish Dis 36:25-33

* Teletchea F, Fontaine P (2014) Levels of domestication in fish: implications for the sustainable future of aquaculture. Fish Fish 15:181-195

*Thorstad EB, Forseth T (2017) Status for norske laksebestander i 2017. Rapport fra Vitenskapelig råd for lakseforvaltning nr. 10. http://hdl.handle.net/11250/2446896 (accessed 14 Oct 2020)

* Thorstad EB, Todd CD, Uglem I, Bjørn PA and others (2016) Marine life of the sea trout. Mar Biol 163:47

* Thorstad EB, Forseth T, Fiske P (2019) Klassifisering av tilstanden til 430 norske sjøørretbestander. Temarapport fra Vitenskapelig råd for lakseforvaltning nr. 7. http:// hdl.handle.net/11250/2629316 (accessed 24 Nov 2020)

* Thorstad EB, Forseth T, Fiske P (2020) Vitenskapelig råd for lakseforvaltning 2020. Status for norske laksebestander i 2020. Rapport fra Vitenskapelig råd for lakseforvaltning nr. 15. https://hdl.handle.net/11250/2657947 (accessed 24 Nov 2020)

*Torrissen O, Jones S, Asche F, Guttormsen A and others (2013) Salmon lice-impact on wild salmonids and salmon aquaculture. J Fish Dis 36:171-194

* Treasurer JW, Wadsworth S, Grant A (2000) Resistance of sea lice, Lepeophtheirus salmonis (Krøyer), to hydrogen peroxide on farmed Atlantic salmon, Salmo salar L. Aquacult Res 31:855-860

* Ugelvik MS, Skorping A, Moberg O, Mennerat A (2017) Evolution of virulence under intensive farming: salmon lice increase skin lesions and reduce host growth in salmon farms. J Evol Biol 30:1136-1142

Submitted: November 25, 2020

Accepted: April 1, 2021

Proofs received from author(s): June 24, 2021 